\title{
強剛な付帯フレームをもつ耐震壁のスリップ破壊せん断強度 SLIP SHEAR STRENGTH OF SHEAR WALLS SURROUNDED WITH REINFORCED AND STIFFENED FRAME
}

\author{
望 月 洵*, 竹 原 雅 夫**, 小野里憲一*** \\ Makoto MOCHIZUKI, Masao TAKEHARA and Norikazu ONOZATO
}

\begin{abstract}
The objectives of this paper are firstly to propose a formula for estimating the slip shear strength of one-bay one-story shear walls surrounded with reinforced and stiffened frame, which simulate multistory framed shear walls, and secondly to examine its validity. The proposed formula is deduced from forty two specimens in the authors' experiment in which all the specimens failed in slip shear failure. The formula is expressed as follows,

$Q_{c a l}=0.313 F_{c} \cdot t \cdot l+\sum_{c} Q_{y}$

where the first term of Eq. ( 1$)$ is the slip shear strength of the wall and the second is the summation of shear forces of the side columns at flexural yielding of their both ends.

In order to examine the validity of Eq. (1), twenty two specimens in the authors' and other researchers' experiments are analyzed by using Eq. (1) and others' previous formulae for comparison. The analytical results show that Eq. ( 1 ) is more adequate than the others' formulae for estimating the maximum strength of the shear walls failed in slip shear failure.
\end{abstract}

Keywords : Slip shear strength, Shear wall, Slip shear failure

\section{1.はじめに}

鉄筋コンクリート構造の保有耐力の確保と剛性の制御 にとって, 連層耐震壁は重要な構造要素であり，その破 壊性状の把握は急務の課題である。連層耐震壁の破壊 モードは, 大要, 側柱の軸引張降伏の生じないせん断破 壊モード，側柱の軸引張降伏が十分に進行している曲げ 破壊モード，およびその中間の曲げ・せん断破壊モード に分類される。本研究は，このうちのせん断破壊モード の強度のみを扱う。

連層耐震壁は，我が国では一般に強剛な基礎梁または 壁で拘束された中間梁をもち，壁板に生じたせん断亀裂 はこの強剛な上・下梁でその伸展が防止される。これか ら，強剛な上・下梁をもつ単独耐震壁に関する知見に よって，連層酎震壁の性状をとらえることが可能と考え られる。この単独耐震壁のせん断破壊モ一ドは，大別し て次のようになる。

a) 耐震壁の側柱の断面が小さく，補強筋量が少ない場 合，壁板に斜め亀裂が生じた後，対角領域の斜め龟裂が 大きく伸展して，抵抗力が増加することなく破壊に至る モード。 b）耐震壁の側柱の断面之補強筋量が中程度の場合，壁 板に斜め亀裂が生じた後もある程度は抵抗力が増加し， 側柱の曲げ破壊またはせん断破壊で破壊に至るモード。 c) 耐震壁の側柱の断面が大きく,補強筋量が多い場合, 壁板に斜め亀裂が生じた後も抵抗力が著しく増加し，付 帯フレームのせん断破壊が生じることなく，壁板の全面 的なスリップ破壊（コンクリートのはく離を伴う圧壊） で最大強度に達するが，その後，付帯フレームだけの抵 抗に移るモード。

これらの破壊モードの力-変位関係を模式的に示せば， 図一1の.ようになる。破壊モード a) とb) は，最大強 度に達すると同時に耐震壁が崩壊する脆性破壊で, 耐震 壁は水平力と鉛直力に対する抵抗力を失う。一方，破壊 モード c) は，最大強度に達した後に急激な強度低下を 示すが付帯フレームの抵抗力は保持されている。すなわ ち, 終局時においても, 耐震壁は側柱の上端と下端の曲 げ降伏に相応するせん断力に，そして側柱に作用する軸 力に抵抗でき，かつ大きな変形性能を示す。また，破壊 モードc) で示す最大強度は, 一般に, 破壊モードa) とb)のいずれよりも大きい。このような破壊モードの

本論文の一部は 1986 年北海道大会, 1987 年近幾大会, 1988 年関東大会, および文献 6)で発表したものである。

* 工学院大学建築学科 助教授

** 東京建築專門学校 教員

Associate Professor of Kogakuin Univ.

*** 工学院大学建築学科 研究助手 


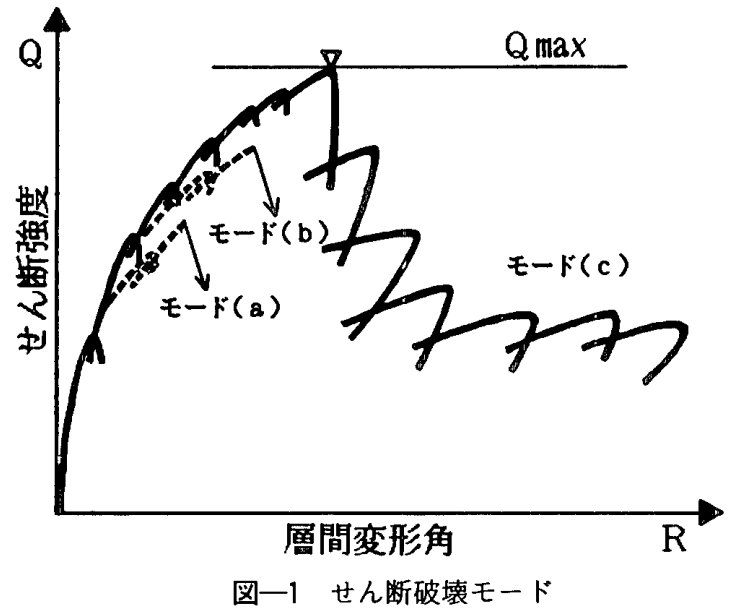

相違を考慮すると, 構造の耐震性確保の立場からは, 耐 震壁のせん断破壊のモードを，破壊モード c）に限定す るのが望ましいといえる。以後, 本研究では, 破壊モ一 ドc）をスリップ破壊といい，スリップ破壊時の最大せ ん断強度をスリップ破壊せん断強度という。

本研究では，第 1 に，曲げ破壊およびせん断破壊しな い強剛な上・下梁とせん断破壊しない側柱をもち, 一方 向対角圧縮力をうける単独耐震壁の実験から，スリップ 破壊せん断強度式を誘導する。そして第 2 に, 強度式誘 導の基礎とした抵抗機構のモデルを用いて，いろいろな 加力条件のもとでスリップ破壊した試験体の解析を行 い, 誘導したスリップ破壊せん断強度式の妥当性を検討 する。

\section{2. 既往のスリップ破壊せん断強度式}

耐震壁のスリップ破壊を扱い，その強度式を提案して いるものとして, 富井・江崎 ${ }^{11}$, 望月 $(\text { 重 })^{2)}$, 徳広ら ${ }^{3)}$, および益尾")の研究がある。いずれも単独耐震壁の実験 を基礎としたものである。

富井・江崎らは, 壁板のスリップ破壊時の最大せん断 応力と平均せん断応力の比が, 弾性応力時のそれと同じ であると仮定して，スリップ破壊せん断強度式を回帰分 析で求めている。このとき, 耐震壁の側柱の効果は弾性 応力にかかわる形状係数の中に考慮されるとして, 強度 式は側柱に関係する項を含まない形になっている。基礎 としたデータには, 一方向対角王縮力 - 他方向対角引張 力の他に曲げ・せん断の加力方法のものが含まれ，一律 に扱っている。これは側柱の効果を考える立場からは問 題が残る。側柱の効果は, 外力の作用状態によって著し い影響をうけるからである。

望月（重）は，ヒンジ結合された銅フレーム内の壁板 に一方向対角圧縮力 ・他方向対角引張力を加えてスリッ プ破壊を生じさせ，これから壁板のスリップ破壊強度を 求めている。さらにこれを用いて, 耐震壁のスリップ破 壊せん断強度式を誘導している。しかし，壁板のスリッ
プ破壊強度をそのまま用いた場合，実験値とかなりの相 違が生じるため, 回帰分析で補正している。このとき, 付帯フレームは弾性状態としている。このため, 側柱の せん断力の評価に軸力の効果が導入されていない。

徳広らは, 鉄骨・鉄筋コンクリートの強剛な付带 レームをもつ耐震壁の片持柱形式の実験から, 耐震壁の スリップ破壊せん断強度式を, 壁板のスリップ破壊せん 断強度と側柱のせん断力の和の形で誘導している。この とき, 付帯フレームは最大強度時において崩壊機構を形 成しているとしているが，その曲げ降伏強度の評価に㧍 いて，側柱に生じる変動軸力を考慮していない。

益尾は, 壁板のスリップ破壊強度には付帯フレームの 拘束が大きな効果をもつとし，この拘束効果を既往の契 験結果から求め, 耐震壁のスリップ破壊せん断強度式を 提案している。しかし，その拘束効果は壁板の強度を高 める形でのみ導入され, 側柱のせん断力の形では導入さ れていない。

本研究は，上に述べた既往の研究と同様に，㫪験から 耐震壁のスリップ破壊せん断強度式を求める方法を採朋 して, 望月（重）, 徳広らと同じ考えに立って, 耐震壁 のスリップ破壊せん断強度は, 壁板のスリップ破壊せん 断強度と側柱のせん断力の和の形で表されるとしてい る。しかし, 望月（重）と異なり, 連層耐震壁在対象と し，上・下梁の曲げ破壊とせん断破壊，および側柱のせ ん断破壊が生じない場合を扱い, 側柱の上端と下端は曲 げ降伏状態にあるとしている。徳広らの研究と, 強剛な 付帯フレームをもつ耐震壁という点では，本研究は同じ 立場にあるが，徳広らの実験では，試験体の多くに側柱 のせん断破壊が生じており, 強度式にこれを考慮してい る。本研究では耐震壁の靶性確保の立場からこ机を除い ている。また, 富井・江崎および望月（重）は定軸力乞 変動軸力を, 徳広らおよび益尾は変動軸力を考愿してい ないが, 本研究では側柱の曲げ降伏強度の評価のとき, 定軸力と変動軸力をともに考慮している。

\section{3. スリップ破壊せん断強度式の基礎とした実駼の概要}

本研究は, 連層耐震壁のスリップ破壊せん断強度式を, 縮小試験体の実験 ${ }^{5,6)}$ から統計的に求める方法をとって いる。夷験の試験体は図一2に示すような形状, 配筋文 もつ単独耐震壁で, 合計 42 体である。付帯フレームの 上・下梁は, 連層耐震壁を模して, 破壊に至るまで曲げ およびせん断破壊が生じないように補強, 補剛されてい る。

試験体の主なパラメータは,コンクリート強度 $F_{c}$, 壁板の補強筋比 $p_{s}$ 亡補強方法, 壁板の形状比 $x=h^{\prime} / l^{\prime}$, ただし $h^{\prime}, l^{\prime}$ はそれぞれ壁板の内法高さと内法長さ，お よび側柱の全主筋比 $p_{g}$ と定軸力 $N_{0}$ である。このうち 壁板の補強方法の種類は, 縦・横配筋, 斜交配節, お上 
表一1 試験体の諸性質と結果

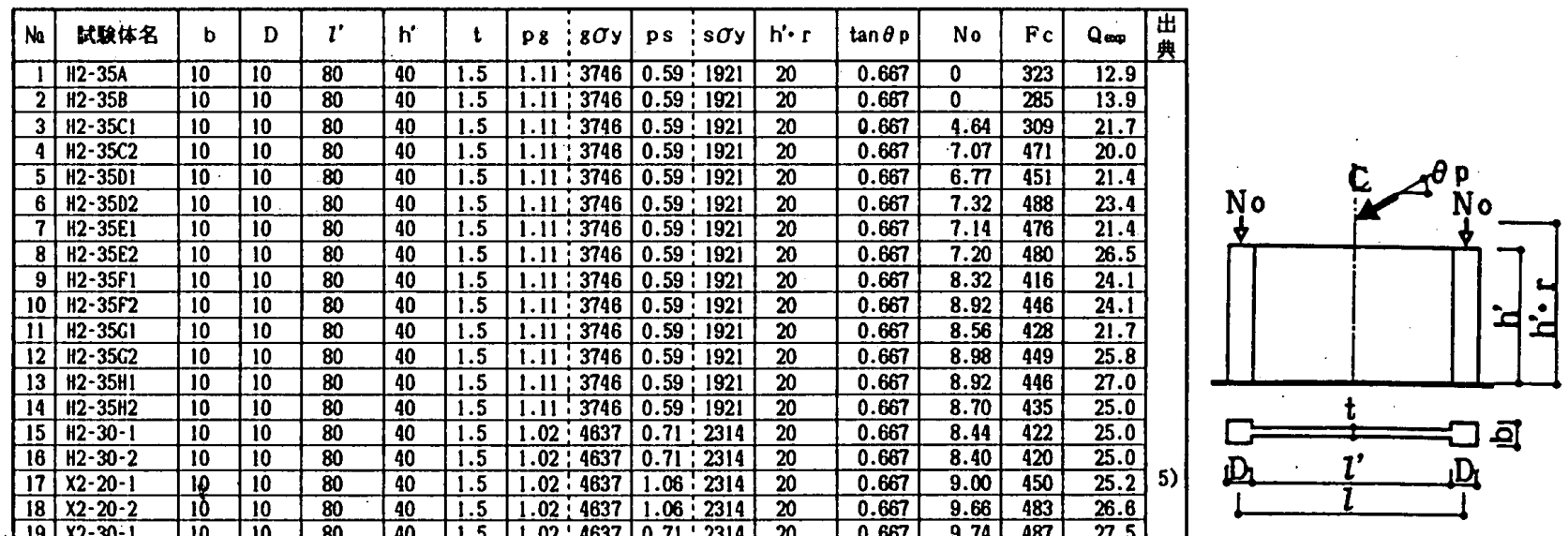

[ 貶 号 ]

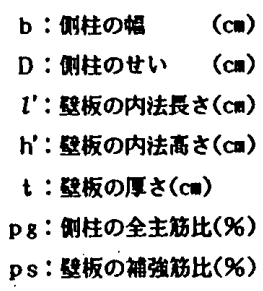

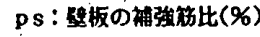

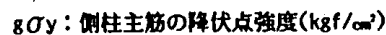

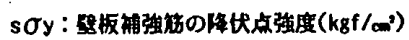

$h^{\prime} \cdot r:$ 反曲点高さ $(\mathrm{cm})$

$r:$ 反曲点高さ比

$\theta p:$ 作用外力の跬鈄角

No: 蛀一本の定䄸力( $t f)$

$\mathrm{Fc}:$ エンクリート压㜚強度 $\left(\mathrm{kgf} / \mathrm{cm}^{3}\right)$

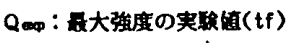

Qcal：而大强度のH其㥀( $(\mathrm{f})$

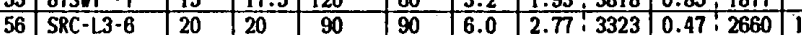

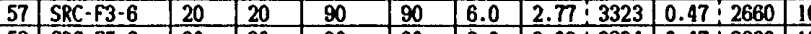

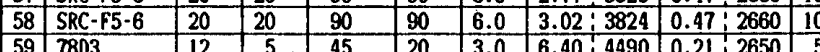

\begin{tabular}{l|l|l|c|c|c|c|c|c|c|c|c|}
59 & 7803 & 12 & 5 & 45 & 20 & 3.0 & 6.40 & 4490 & 0.21 & 2650 \\
\hline 60 & $\mathrm{RCV}-1$ & 12.5 & 12.5 & 107.5 & 47.5 & 4.0 & 1.08 & 3705 & 0.30 & 2489 \\
\hline
\end{tabular}

\begin{tabular}{l|l|l|l|l|l|l|l|l|l|l|l|}
61 & $\mathrm{RCV}-2$ & 12.5 & 12.5 & 107.5 & 47.5 & 4.0 & 1.08 & 3705 & 0.30 & 2489
\end{tabular}

\begin{tabular}{l|l|l|l|l|l|l|l|l|l|l|}
62 & $\mathrm{RCV}-3$ & 12.5 & 12.5 & 107.5 & 47.5 & 2.0 & 1.80 & 3870 & 0.60 & 2494 \\
\hline
\end{tabular}

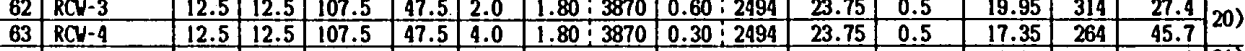

\begin{tabular}{|l|l|l|l|l|l|l|l|l|l|l|l|l|l|l|l|l|l|}
\hline 63 & HALL & 30 & 30 & 170 & 105 & 8.0 & 1.04 & 4354 & 1.19 & 4152 & 120 & 0 & 63.2 & 235 & 149.8 & 211 \\
\hline
\end{tabular}

び壁板の小孔の有無である。表一1 に試験体番号 No.1

〜 42 として試験体の諸性質を示す。

加力はオイルジャッキ(最大能力：30 tf または $50 \mathrm{tf}$ ) による一方向対角圧縮交番力で, 最大荷重時までは荷重 制御，それ以降は変位制御とした。側柱に作用する定軸 力は，側柱に埋設されたビニールパイプを通る PC 鋼 棒 $(13 \phi)$ に引張力を導入することで加えられ， PC 鋼 棒のひずみ測定からその引張力が実験の間一定になるよ う調節された。

42 体すべての試験体が，1. で定義したスリップ破壊 で最大強度に達し，その破壊経過のステップは，大要， 同じもので次のようである。
1）層間変形角 $R=0.25 \times 10^{-3} \mathrm{rad}$, 程度で，壁板にほ ぼ $45^{\circ}$ および $135^{\circ}$ に傾いた初斜め亀裂が生じる。

2）壁板に直交した斜め龟裂網が形成される。

3）側柱の上端と下端に曲げ亀裂が生じる。

4）壁板の斜め亀裂が増し，拡幅が著しくなる。

5）壁板に局部的なスリップ破壊が持続的に生じる。

6) $R=4 \times 10^{-3} \sim 5 \times 10^{-3} \mathrm{rad}$. 程度で，壁板の全面的な スリップ破壊が生じて最大強度に達し，急激な強度低下 を示す。破壊は, 側柱と上・下梁に沿う領域, そして対 角領域で著しい。

7）壁板と付帯フレームの一体構造としての働きを失 い，側柱の上端と下端の曲げ降伏の形で抵抗する。 


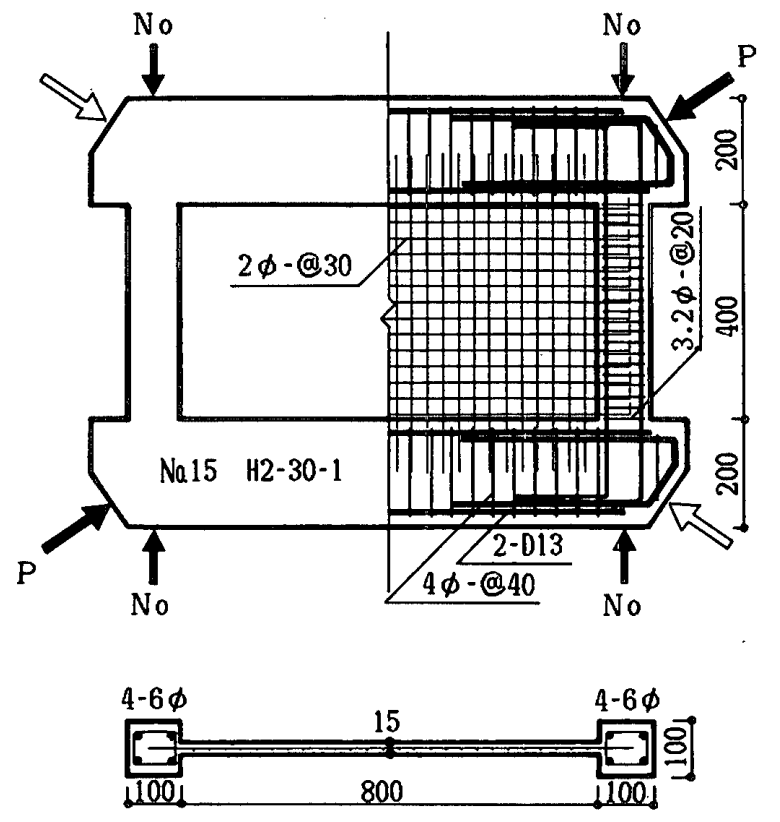

図一2 試験体例

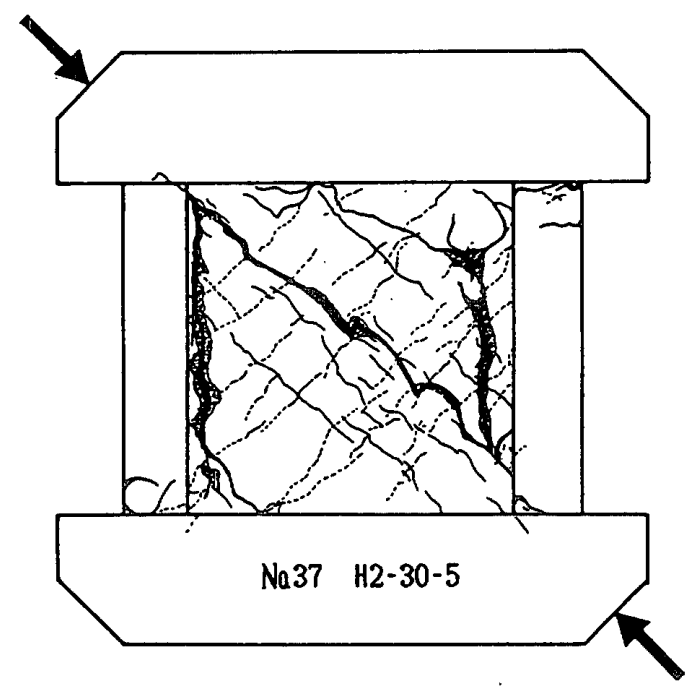

图一3 最大強度時の亀裂状況

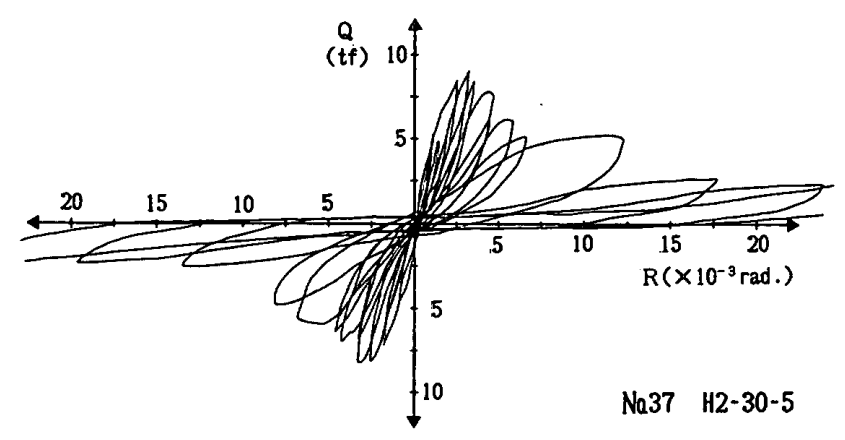

図一4 せん断力-層間変形角の関係

このような破壊経過には,コンクリート強度, 壁板の 補強筋比亡補強方法, 壁板の形状比, および側柱の全主 筋比と定軸力などのパラメータによる相違は観察されて いない。表一1に実験の最大せん断強度を, 図一 3 お

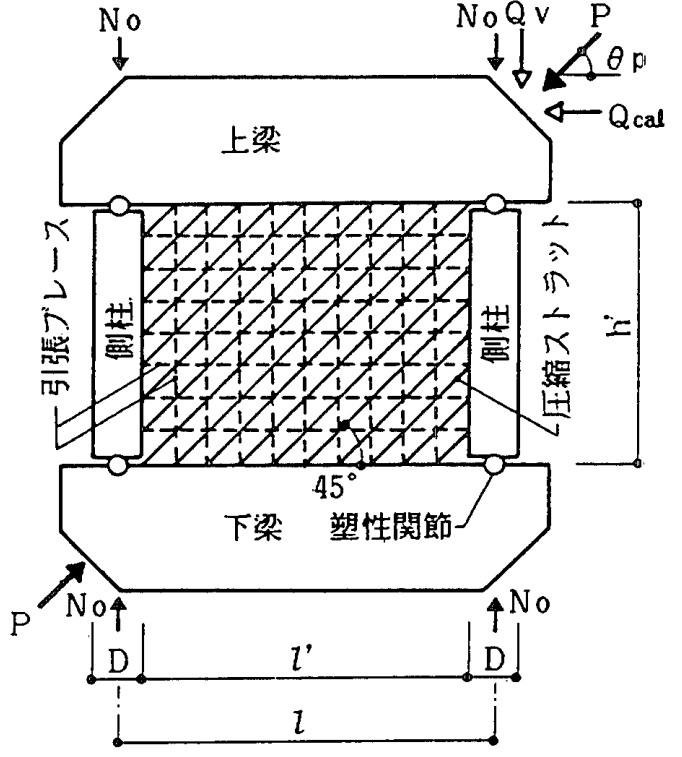

$P:$ スリッ丁陂犊時作用外力

Qv: スリッ丁破填時作用外力の鉿直成分

Qcal：スリッ丁破焃昨用外力の水平成分

図一5 モデル

び 4 に, 最大強度時の亀裂状況, せん断力-層間変形角 の関係として試験体番号 No. 37：H2-30-5 の例を示す。

\section{4. スリップ破壊せん断強度式の誘導}

\section{1 抵抗機構のモデルと仮定}

耐震壁のスリップ破壊せん断強度式を誘導するため に, 実験の破壊性状に基づりて次の抵抗機構の:Eデルを

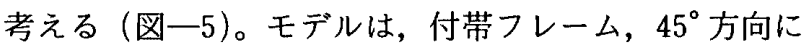
傾斜したコンクリートの圧縮ストラット，および縦・横 の引張ブレースで構成される。

モデルの各構成要素はスリップ破壊時において次の状 態にあると仮定する。

1）付帯フレームの上・下梁は, 終始, 破壊することな く変形もしない。

2）付帯フレームの側柱は，上端と下端において曲げ降 伏して塑性関節を形成しているが，引張りまたは圧縮の 軸降伏の状態になく, また, その中間部は弾性状態で, スリップ破壊時のせん断力によって破壊しない。ここで, 側柱の曲げ降伏強度は定軸力と変動軸力を考慮して表-2 の柱の終局強度式7で評価される。

3）圧縮ストラットの応力は一様で，コンクリートのス リップ破壊強度で降伏している。このスリップ被壊強度 はコンクリートの圧縮強度の 1 次関数で表される。

4）縦・横の引張ブレースはともに降伏している。

1）の仮定は，すべての試験体の上・下梁が十分大き い断面と補強筋をもっていること，また実験でも上・下 梁に亀裂の発生がなかったことに基づいている。

2）の仮定は，スリップ破壊時に側柱の上端よ下端に 
表一2 柱の終局強度式

$\mathrm{N} \max \geq \mathrm{Nc}>0.4 b \cdot \mathrm{D} \cdot \mathrm{F} c$ 堨合

$\mathrm{My}=\mathrm{b} \cdot \mathrm{D}^{2} \cdot(0.4 \mathrm{pg} \cdot \mathrm{g} \sigma \mathrm{y}+0.12 \mathrm{Fc}) \frac{\mathrm{N} \max -\mathrm{Nc}}{\mathrm{N} \max -0.4 \mathrm{~b} \cdot \mathrm{D} \cdot \mathrm{Fc}}$ $0.4 \mathrm{~b} \cdot \mathrm{D} \cdot \mathrm{Fc} \geqq \mathrm{Nc}>0$ の場合

$M y=0.4 p g \cdot g \sigma y \cdot b \cdot D^{2}+0.5 N c \cdot D \cdot\left(1-\frac{N c}{b \cdot D \cdot F c}\right)$ $0>\mathrm{NcZ} \mathrm{Nmin}$

$\mathrm{My}=0.4 \mathrm{p} \mathrm{g} \cdot 8 \sigma \mathrm{y} \cdot \mathrm{b} \cdot \mathrm{D}^{2}+0.4 \mathrm{NcD}$

ただし $\mathrm{N}$ max：轴压耠降伏強度 $=\mathrm{b} \cdot \mathrm{D} \cdot(\mathrm{Fc}+\mathrm{pg} \cdot \mathrm{g} \sigma \mathrm{y})$

Nmin : 軸引張降伏強度 $=-p g \cdot 8 \sigma y \cdot b \cdot D$

$\mathrm{Nc}$ ：别柱の方向力

My：側柱の曲计降犾強度

曲げ亀裂が生じ，スリップ破壊以降は側柱の上端と下端 の曲げ降伏の形で抵抗したこと，そして側柱にせん断亀 裂が生じたもののせん断破壊は生じなかったことに基つ いている。

3）の仮定は，コンクリートの脆性的な性質を考える と問題が残るが，実験の破壊状況で，局部的なスリップ 破壊が持続した後に，全面的なスリップ破壊が生じたこ とに基づいている。

また，4）の仮定は，壁板補強筋のひずみ測定をして いないことから確認できないが，抵抗機構の簡単化のた めに設定したものである。

このような抵抗機構のモデルについては，2.で述べ た既往のスリップ破壊せん断強度式を誘導するためのモ デとは別に，耐震壁の最大強度を極限解析の下界定理に 基づいて求めるためのモデルが，称原・加藤 ${ }^{81}$ ，白石・ 狩野9)，南・村上年，および塩原"'加ら提案されている。 これらは一般的に有限要素法のミクロモデルに対比して マクロモデルといわれる。本研究で設定したモデルは, 筆者ら ${ }^{121}$ が提案している連層耐震壁のマクロモデルを簡 略化したものであるが，既往のマクロモデルとは次の点 で巽なる。

a) 対象をせん断破壊モードに限定している。

b）両側柱のせん断抵抗を考虑している。

c) 側柱の上端と下端のみの曲げ降伏を仮定している。

d）圧縮ストラットの傾斜角を $45^{\circ}$ に限定している。

設定したモデルのもとで，耐震壁のスリップ破壊せん 断強度 $Q_{c a l}$ は次のように表される。

$$
Q_{c a l}={ }_{w} Q+{ }_{c} Q
$$

ここで， ${ }_{w} Q$ は圧縮ストラットと縦・横の引張ブレー スで構成される壁板のスリップ破壊時のせん断力で次式 で表される。

$$
{ }_{w} Q={ }_{w} \tau \cdot t \cdot l^{\prime}
$$

ただし， $\omega \tau$ は壁板のスリップ破壊せん断強度， $t$ は壁 板の板厚である。

また， ${ }_{c} Q$ は両側柱のせん断力の和で，一方向対角圧 縮力のもとで応力分布が対称であることを考慮すれば，

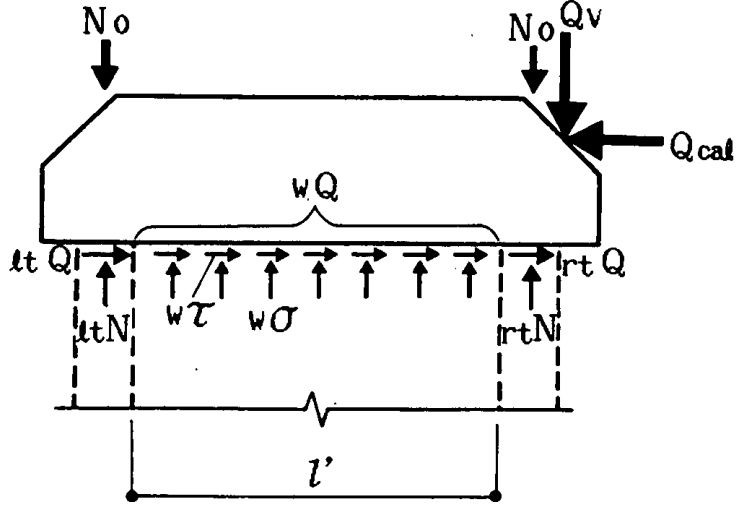

(a)

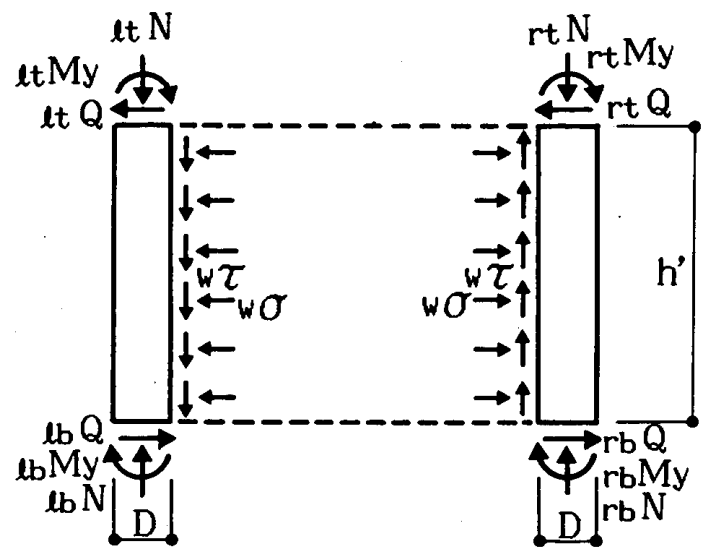

( b )

$w \tau$ : 壁板のスリッブ破丧時接線応力成分 $w \sigma$ : 壁板のスリッフ破媴時垂直応力成分 et $N 、$ lt $M y 、$ lt $Q$ 、および $\mathrm{b} N$ 、lbMy ebQは左側柱上端および下端の応力 $\mathrm{rt} N$ 、 $r t M y, r t Q 、 お よ U r b N 、 r b M y, r b Q は$ 右例柱上端およひ下端の応力

图一6 モデルの応力と記号 I

図一6の記号之左側柱の釣合いから，次のようになる。

$$
{ }_{c} Q={ }_{w} \tau \cdot t \cdot D+2\left({ }_{u} M_{y}+{ }_{\iota b} M_{y}\right) / h^{\prime}
$$

ただし， $D$ は側柱のせい, ${ }_{t t} M_{y},{ }_{t b} M_{y}$ はそれぞれ左側柱 の上端と下端の曲げ降伏強度である。

ここで, ${ }_{c} Q_{y}=\left({ }_{l t} M_{y}+{ }_{l b} M_{y}\right) / h^{\prime}$ とおけば, 式（1）は 次のようになる。

$$
Q_{c a l}={ }_{w} \tau \cdot t \cdot l+2 \cdot{ }_{c} Q_{y} \cdot
$$

ただし，lは両側柱の芯々間距離である。

結局，壁板の寸法として，l' の代わりにlを用いれば よい。以降において, 式（4）の初項を ${ }_{w} Q$ 之定義する。

\section{2 誘導の手順}

式（4）の初項は, 縦の引張ブレースが水平方向の力 の成分をもたないため，次のようになる。

$$
{ }_{w} \tau \cdot t \cdot l={ }_{c} \tau \cdot t \cdot l \cdot
$$

ただし， ${ }^{\tau} \tau$ は圧縮ストラットのスリップ破壊せん断強 度である。 ${ }^{2} \tau$ は 4.1 の仮定 3）からコンクリート強度の 1 次式として次のように表される。 


$$
{ }_{c} \tau=\alpha \cdot F_{c}+\beta
$$

式（6）の係数 $\alpha$ と $\beta$ は, 実験デー夕を用いて次の 手順で決定される。

1) 適当な $\alpha$ と $\beta$ を設定する。

2) 各試験体について，最大せん断強度の実験值 $Q_{\exp }$ と1）で設定した $\alpha, \beta$ を用いて求めた ${ }_{c} \tau$ から，側柱の 上端と下端の軸力を求める。

3）各試験体について 2) で求めた軸力を用いて, 側柱 の上端と下端の曲げ降伏強度 ${ }_{t t} M_{\boldsymbol{y}}$ と ${ }_{t b} M_{\boldsymbol{y}}$ を求める。

4) 式（4）と（5）から， $Q_{c a l}$ を $Q_{\exp }$ とおいて, ${ }_{c} \tau$ を求める。

5）各試験体について 4) で求めた 団として，式（6）が最もよく適合する係数 $\alpha$ と $\beta$ を 最小 2 乗法で求める。

6） 2) 5）を，係数 $\alpha$ と $\beta$ の值が小数点以下第 5 位の 析で変化しなくなるまで繰り返す。

\section{3 スリップ破壊せん断強度式}

表-1のNo.1〜42 の実験データを用いて, 4.2 の手 順をモデルに適用した結果，式（6）の係数 $\alpha$ と $\beta$ に ついて, 次の結果を得た。

$$
\alpha=0.313, \quad \beta=-0.4
$$

ここで，有孔壁も無孔壁と同じに扱った。

式（7）の $\beta=-0.4$ が小さいため，これを省略する と, 一方向対角圧縮力をうける耐震壁のスリップ破壊せ ん断強度式として次の式を得る。

$$
Q_{\text {cal }}=0.313 F_{c} \cdot t \cdot l+2 \cdot{ }_{c} Q_{y} \cdot
$$

強度式（8）の圧縮ストラットのスリップ破壊せん断 強度 $0.313 F_{c}$ は，後出の徳広らの強度式 (11) で拘束 が大きい場合，および益尾の強度式 (15) の $F_{c}=300$ $\mathrm{kg} / \mathrm{cm}^{2}$ 程度の場合と極めて近いが，富井・江崎および 望月（重）の強度式（9）と（10）とは著しく相違して いる。いずれの強度式においても，付帯フレームを除く 壁板の抵抗機構のモデルは, 大要, 同じであるから,こ の相違は, 基礎とした試験体の付帯フレームの断面寸法 とその取扱いに起因している。

式（8）の0.313 $F_{c}$ は，圧縮ストラットの軸方向圧 縮強度としては $0.626 F_{c}$ を与える。これは，生縮力の 方向と平行な亀裂が生じている壁板コンクリートの有効 圧縮強度に相当する。既往のマクロモデルによる耐震壁 の最大強度の解析では, 有効圧縮強度として, $0.7 F_{c} \sim$ $1.0 F_{c}$ の值が採用されている8) 11)。この有効任縮強度 について，野口ら ${ }^{13)}$ は，壁板の二方向加力実験から次の 結果を示している。すなわち，一方向引張力を壁板に亀 裂が生じ補強筋が降伏するまで加え，さらに直交する圧 縮力を破壊するまで加える実験から，有効圧縮強度は, 平均亀裂幅の広い範囲でほぼ $0.6 F_{c}$ に近い值である。 これは, 式（8）の結果によく相応している。

式 $(8)$ の初項は $F_{c}$ から直接的に求まるが, 第 2 項
表-3 計算の手順

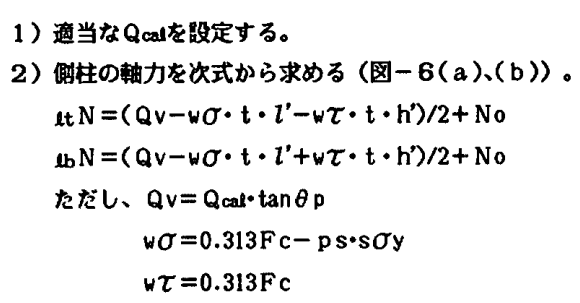

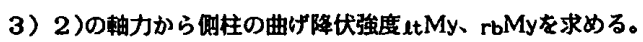
ただし、軸力が降伏強度を超える堨合、曲外降状強度は零とする。

4) Qcal $=w \tau \cdot t \cdot l+2(l t M y+l b M y) / h$ 'を求める。

5）Qcaltb収束するまで2)〜4)を細り返す。

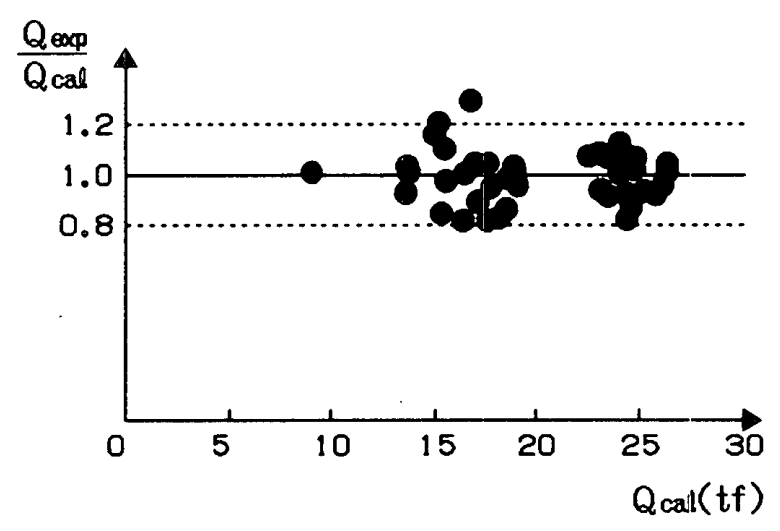

图一7 強度式（８）による $\frac{Q_{\text {exp }}}{Q_{c a l}}$

は繰返し計算が必要である。表一3に繰返し計算の手順 を示す。表一4 に, 式 $(8)$ による計算值 $Q_{c a l}$ と計算 値に対する実験值の比 $Q_{\text {expo }} / Q_{c a l}$, および ${ }_{c} Q / Q_{c a l}$ の値 を示す。 $Q_{\text {exo }} / Q_{c a l}$ の平均, 標準偏差, および変動係数 の值は，0.994，0.107 および0.108で，42体のうち2 体を除き，計算値はその土 $20 \%$ の範囲に奉験値をとら えており (図一7), 式（8）で $\beta$ を省略したことによ る影響はないといえる。また，式（8）の計算値と実䮖 値との相関係数は 0.907 で,十分強い相関が認められる。

\section{5. スリップ破壊せん断強度式の検討}

\section{1 既往の強度式}

本章以降で, 提案強度式（8）を検討するにあたって, 比較のため既往の強度式を引用している。この之き，対 象とした試験体の寸法を考慮して次の式を用いた。

富井・江崎の強度式：

$$
Q_{u 0(w s)}=\left(2.4 \sqrt{F_{c}}+3400 p_{s}\right) \cdot t \cdot l
$$

望月（重）の強度式：

$$
\begin{aligned}
Q_{s, H}= & \frac{1}{\xi}\left\{0.46 C_{s, 1}\left(F_{c}+139\right)\right. \\
& \left.+0.50 C_{s, 2} \cdot p_{s} \cdot{ }_{s} \sigma_{s}\right\} \cdot t \cdot l \\
C_{s, 1}= & \frac{q\left\{3 \mu(1+k)+\mu^{2}+k\right\}}{6 \mu(1+k)}
\end{aligned}
$$


表一4 解析結果

\begin{tabular}{|c|c|c|c|c|c|c|c|c|c|c|c|c|c|}
\hline \multirow[b]{2}{*}{$\mathrm{Na}$} & \multirow[b]{2}{*}{ 軾験休名 } & \multirow{2}{*}{$\begin{array}{c}\text { 実䐓值 } \\
Q_{\operatorname{mop}} \\
(\mathrm{tf})\end{array}$} & \multicolumn{3}{|c|}{ 悘案式 } & \multicolumn{2}{|c|}{ 富井・江䗁式 } & 晊月 & T)式 & & & & \\
\hline & & & $\begin{array}{l}Q \mathrm{cal} \\
(\mathrm{tf})\end{array}$ & Q $\frac{\operatorname{sep}}{\text { cal }}$ & $\frac{c \bar{Q}}{Q \mathrm{cal}}$ & $\begin{array}{l}\text { Qcal } \\
\text { (tf })\end{array}$ & $\frac{Q_{\exp }}{Q_{\text {cal }}}$ & $\begin{array}{l}\text { Qcal } \\
\text { (tf) }\end{array}$ & $\frac{Q_{\text {Exp }}}{Q_{\text {cal }}}$ & $\begin{array}{l}\text { Qcal } \\
\text { (tf) }\end{array}$ & $\frac{Q_{e q}}{Q_{\text {cal }}}$ & $\begin{array}{l}Q_{\text {cad }} \\
(t f)\end{array}$ & $\frac{Q_{\text {exp }}}{Q_{\text {cal }}}$ \\
\hline 1 & $\mathrm{H} 2-35 \mathrm{~A}$ & 12.9 & 15.27 & 0.842 & 0.11 & 8.53 & 1.512 & 7.49 & 1.722 & 5.37 & 2.402 & 14.99 & 0.861 \\
\hline 2 & $-35 B$ & 3.9 & 3.74 & 1.009 & 0.12 & 8.18 & 1.699 & 6.97 & 1.994 & 5.19 & 2.678 & 13.94 & 0.997 \\
\hline 3 & $\mathrm{Cl}$ & .7 & 6.71 & 1.296 & 0.22 & 8.40 & 2.583 & 7.29 & 2.977 & 9.41 & 2.306 & & \\
\hline 4 & $2-35 \mathrm{C} 2$ & 0.0 & 24.35 & 0.819 & 0.18 & 9.74 & 2.053 & 9.51 & 2.103 & 12.33 & 1.622 & 17.66 & 1.133 \\
\hline 5 & $2-3501$ & 21.4 & 23.40 & 0.912 & 0.19 & 9.59 & 2.231 & 9.23 & 2.319 & 11.97 & 1.788 & 17.43 & 1.228 \\
\hline 6 & & 3.4 & 25.14 & 0.928 & 0.18 & 9.87 & 2.371 & 9.74 & 2.402 & 12.63 & 1.853 & 17.83 & \\
\hline 7 & $2-35 E 1$ & 21.4 & 24.58 & 0.869 & 0.18 & 9.78 & 2.188 & 9.58 & 2.234 & 12.42 & 1.723 & 17.71 & 1.208 \\
\hline$\overline{8}$ & $2-35 E 2$ & 26.5 & 24.77 & 1.067 & 0.18 & 9.81 & 2.701 & 9.63 & 2.752 & 12.49 & 2.122 & 17.75 & 1.493 \\
\hline 9 & & .1 & 22.50 & 1.069 & 0.22 & 9.32 & 2.586 & 8.76 & 2.751 & 12.93 & 1.864 & 16.93 & 1.424 \\
\hline 10 & $2-35 F 2$ & 24.1 & 23.97 & 1.003 & 0.21 & 9.55 & 2.524 & 9.17 & 2.628 & 13.58 & 1.775 & 17.37 & 1.387 \\
\hline 11 & $2-35 \mathrm{Gl}$ & 21.7 & 23.08 & 0.938 & 0.22 & 9.41 & 2.306 & 8.92 & 2.433 & 13.19 & 1.645 & 17.12 & 1.268 \\
\hline 12. & & 25.8 & 24.12 & 1.067 & 0.21 & 9.57 & 2.696 & 9.21 & 2.801 & 13.65 & 1.890 & 17.41 & 1.482 \\
\hline 13 & $2-35 \mathrm{HI}$ & 27.0 & 23.97 & 1.124 & 0.21 & 9.55 & 2.827 & 9.17 & 2.944 & 13.57 & 1.990 & 17.37 & 1.554 \\
\hline 14 & $2-3$ & 25.0 & 23.43 & 1.065 & 0.22 & 9.47 & 2.640 & 9.02 & 2.772 & 13.32 & 1.877 & 17.22 & 1.452 \\
\hline 15 & 1 & 25.0 & 23.14 & 1.078 & 0.23 & 9.92 & 2.520 & 9.36 & 2.671 & 13.90 & 1.799 & 17.42 & 1.435 \\
\hline 16 & $2-30-2$ & 25.0 & 23.04 & 1.082 & 0.23 & 9.90 & 2.525 & 9.34 & 2.677 & 13.85 & 1.805 & 17.39 & 1.438 \\
\hline 17 & $\times 2-20-1$ & 25.2 & 24.66 & 1.019 & 0.23 & 11.74 & 2.147 & 10.58 & 2.382 & 15.51 & 1.625 & 18.39 & 1.370 \\
\hline 18. & $\times 2-20-2$ & 26.6 & 26.29 & 1.009 & 0.22 & 11.99 & 2.219 & 11.04 & 2.409 & 16.27 & 1.635 & 18.71 & 1.422 \\
\hline 19 & $\times 2-30-1$ & 27.5 & 26.33 & 1.042 & 0.22 & 10.41 & 2.642 & 10.25 & 2.683 & 15.39 & 1.787 & 18.17 & 1.513 \\
\hline 20 & $\times 2-30-2$ & 24.9 & 26.09 & 0.952 & 0.22 & 10.37 & 2.401 & 10.18 & 2.446 & 15.28 & 1.630 & 18.13 & 1.373 \\
\hline 21 & H02-30-1 & 22.5 & 24.37 & 0.921 & 0.23 & 10.11 & 2.226 & 9.71 & 2.317 & 14.47 & 1.555 & 17.76 & 1.267 \\
\hline 22 & H02 & 23.7 & 25.74 & 0.918 & 0.22 & 10.32 & 2.297 & 10.09 & 2.349 & 15.12 & 1.567 & 18.07 & 1.312 \\
\hline 23 & H02 & 13.3 & 16.32 & 0.813 & 0.28 & $8: 65$ & 1.538 & 7.16 & 1.858 & 9.76 & 1.363 & 13.97 & 0.952 \\
\hline 24 & H02 & 15.2 & 17.06 & 0.889 & 0.28 & 8.80 & 1.727 & 7.37 & 2.062 & 10.11 & 1.503 & 14.41 & 1.055 \\
\hline 25 & H02-30-3 & 16.5 & 16.42 & 1.003 & 0.30 & 8.59 & 1.921 & 7.08 & 2.331 & 11.65 & $1 . \overline{416}$ & 13.79 & 1.197 \\
\hline 26 & 1102 & 15.9 & 18.49 & 0.858 & 0.27 & 9.06 & 1.755 & 7.75 & 2.052 & 11.43 & 1.391 & 15.17 & 1.048 \\
\hline 27 & $\times 2-3$ & 18.4 & 17.60 & 1.043 & 0.27 & 8.90 & 2.067 & 7.52 & 2.447 & 10.96 & 1.679 & 14.72 & 1.250 \\
\hline 28 & $\mathrm{H} 2$. & 18.3 & 18.58 & 0.983 & 0.27 & 9.08 & 2.015 & 7.79 & 2.349 & 11.42 & 1.602 & 15.25 & 1.200 \\
\hline 29 & $x_{02}$ & 15.0 & 18.14 & 0.825 & 0.27 & 9.00 & 1.667 & 7.67 & 1.956 & 11.22 & 1.337 & 15.02 & 0.999 \\
\hline 30 & $x 02$ & 15.1 & 15.48 & 0.974 & 0.29 & 8.48 & 1.781 & 6.93 & 2.179 & 9.98 & 1.513 & 13.45 & 1.123 \\
\hline 31 & $\times 02$ & 16.9 & 17.74 & 0.951 & 0.30 & 8.83 & 1.914 & 7.42 & 2.278 & 11.94 & 1.415 & 14.53 & 1.163 \\
\hline 32 & & 183 & 1517 & 1.204 & 0.31 & 8.35 & 2.192 & 6.75 & 2.711 & 10.63 & 1.722 & 13.03 & 1.404 \\
\hline 33 & $w \times 2$ & 19.3 & 18.96 & 1.016 & 0.27 & 10.83 & 1.782 & 8.63 & 2.236 & 12.43 & 1.553 & 16.02 & 1.205 \\
\hline 34 & $W \times 2$ & 19.5 & 18.86 & 1.032 & \begin{tabular}{|l|}
0.27 \\
\end{tabular} & 10.81 & 1.804 & 8.60 & 2.267 & 12.39 & 1.574 & 15.97 & 1.221 \\
\hline 35 & $W \times 0$ & 18.2 & 19.06 & 0.953 & 0.27 & 10.84 & 1.679 & 8.66 & 2.102 & 12.48 & 1.458 & 16.06 & 1.133 \\
\hline 36 & $\overline{W X O}$ & 17.6 & 16.88 & 1.040 & 0.28 & 10.44 & 1.686 & 8.06 & 2.184 & 11.47 & 1. & 14.92 & 1.180 \\
\hline 37 & $\mathrm{H} 2$ & 9 & 9.03 & 1.007 & 0.31 & 5.38 & 1.691 & 4.76 & 1.912 & 6.36 & 1.431 & 8.15 & 1.117 \\
\hline 38 & $\mathrm{H} 2-30-6$ & 17.4 & 14.95 & 1.162 & \begin{tabular}{|l|}
0.27 \\
\end{tabular} & 6.42 & 2.710 & 6.44 & 2.702 & 8.91 & 1.953 & 11.16 & 1.559 \\
\hline 39 & & 17.0 & 15.45 & 1.098 & 0.27 & 6.49 & 2.619 & 6.58 & 2.584 & 9.12 & 1.864 & $11 . \overline{33}$ & 1.500 \\
\hline 40 & II2. & 14.3 & 17.52 & 0.814 & 0.16 & 11.15 & 1.283 & 9.23 & 1.549 & 10.65 & 1.343 & 17.75 & 0.806 \\
\hline 41 & $\mathrm{H} 2 . \overline{8}$ & 14.1 & 13.69 & 1.028 & 0.23 & 7.59 & 1.858 & 6.82 & 2.067 & 7.66 & 1.841 & 12.32 & 1.144 \\
\hline 42 & $0-3$ & 12.6 & 13.62 & 0.922 & $0 . \overline{23}$ & 7.59 & 1.660 & 6.82 & 1.848 & 7.29 & 1.728 & 12.32 & 1.023 \\
\hline 43 & H2- & 8.0 & 8.97 & 0.891 & 0.31 & 5.58 & 1.434 & 4.85 & 1.649 & 7.73 & 1. & 8.22 & 0.973 \\
\hline 44 & $\mathrm{H} 2$ & 9.6 & 10.36 & 0 & 0. & 6.18 & 1.553 & .57 & 1.724 & 8.35 & 1. & 9.70 & 0.990 \\
\hline 45 & H2- & 9.7 & 10.68 & 0.907 & 0.2 & 6.38 & 1.520 & 20 & 1.672 & 8.43 & 1.15 & 10.15 & 0.956 \\
\hline 46 & & 8 & 9.28 & 7 & 0.29 & & 1.5 & & 1.752 & $\overline{7.83}$ & 1. & 8.67 & 1.027 \\
\hline 47 & $\mathrm{H} 2$ & 8.4 & 8.73 & 0.960 & 0.31 & 5.65 & 1.487 & 4.90 & 1.71 & 7.51 & 1.11 & 8.22 & 1.022 \\
\hline 48 & & 22.7 & 25.45 & 0.889 & 0.18 & 14.78 & 1.536 & 11.89 & 1.909 & 10.80 & 2.102 & 23.77 & 0.955 \\
\hline 49 & 865 & 24.2 & 28.17 & 0.857 & $\begin{array}{l}0.22 \\
\end{array}$ & 15.05 & 1.608 & 12.27 & 1.97 & 12.03 & 2.012 & 24.55 & 0.986 \\
\hline 50 & Occ & 23.4 & 24.82 & 0 & 0. & $=1$ & 1.9 & & & & & 22.61 & 1.035 \\
\hline 51 & 875 & 70 & 19 & 0 & 0 & & & 14. & & 18.39 & 1. & 24.75 & 1.196 \\
\hline 52 & 875 & 35.8 & 31.01 & 1.152 & 0.27 & 20.57 & 1.740 & $=$ & 2. & 17.75 & 2.017 & 29.20 & 1.226 \\
\hline$\overline{53}$ & & 41.5 & & & & & & $18 . \overline{06}$ & 2. & 20.74 & 2. & 33.43 & 1.241 \\
\hline 54 & 875 & 36.1 & 34.70 & 1.038 & 0. & 25.60 & 1.410 & 19.09 & 1.891 & 19.76 & 1. & 35.47 & 1.018 \\
\hline 55 & & 40 & & 0.921 & & 29.25 & 1.395 & 22.43 & & 23.21 & 1. & 42.75 & 0.954 \\
\hline 56 & & 40.8 & 50 & 0.806 & & 32.21 & 1.2 & 30.70 & 1.3 & 39.23 & 1.040 & 52.18 & 0.782 \\
\hline 57 & & 46 & & 0. & & 32. & 1. & 30.70 & & & & & \\
\hline 58 & & 47 & 2 & & & 33. & & 32.77 & 1 & 52.51 & & 57.39 & 0.833 \\
\hline 59 & 780 & 13.2 & 13.24 & 0.995 & 0.29 & 6.16 & 2.143 & 5.72 & 2.308 & 10.37 & 1.273 & 11.65 & 1.133 \\
\hline 60 & & 46 & & & & 24.51 & 1.889 & 23.28 & 1.989 & 33.32 & 1.390 & 48.86 & 008 \\
\hline 61 & & 44.7 & 49.15 & 0.907 & 12 & 24.48 & 1.826 & 23.23 & 1.924 & 25.10 & 1.781 & 48.75 & 0.917 \\
\hline 62 & $\mathrm{RCL}$ & 27.4 & 33.39 & 0.8 & 0.29 & 15.10 & 1.815 & 13.59 & 2. & 28.85 & & 26.80 & \\
\hline 63 & RCW-4 & 45.7 & 4 & & 0.16 & 23.61 & 1.936 & 22.04 & 2. & 38.67 & 1. & 46.02 & 0.993 \\
\hline$\frac{54}{64}$ & WALL & 149.8 & 146.07 & 1.023 & 0.19 & 123.60 & 1.212 & 123.00 & 1.218 & 140.09 & & 189.45 & \\
\hline & $\mathrm{Na} i \sim$ & & & 0.994 & 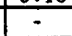 & 0.0 & 2.125 & 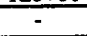 & 2.3 & . & 1.7 & - & 1.255 \\
\hline & $\mathrm{NaI} \sim 42 \sigma$ & 㻞差 & - & 0.1 & - & $\because$ & 0.408 & - & 0.337 & & 0.2 & - & \\
\hline & & & & & - & & 0.1 & & 0.144 & & 0.165 & - & 0.154 \\
\hline & Na 43 & F均 & - & 0.934 & - & $=$ & 1.607 & 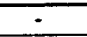 & 1.8 & & 1.446 & $=$ & 0.995 \\
\hline & & & & & & & 0. & & 0. & & 0.2 & - & 0.123 \\
\hline & Na $43 \sim 64 \sigma$ 齐 & 係数 & & 0.092 & - & - & 0.145 & 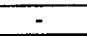 & 0.160 & 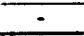 & 0.298 & $=$ & 0.123 \\
\hline & 全 体 & 均 & - & 0.973 & & - & 1.947 & $\because$ & 2.173 & & 1.625 & & 1.16 \\
\hline & 全休の標 & 㴜童 & & 0.103 & - & & 0.434 & & 0.400 & - & 0.362 & - & 0.211 \\
\hline & 全体の変 & & & 0.106 & & & 0.223 & & 0.184 & & 0.223 & & 0.18 \\
\hline
\end{tabular}




$$
C_{s, 2}=\frac{3 \mu(1+p)(1+k)+(1+p-2 \xi)\left(\mu^{2}+k\right)}{6 \mu(1+k)}
$$

ただし， $\xi=1.2 ，(p, q)=(2.15,0.46),{ }_{s} \sigma_{y}$ は壁板補強 筋の降伏強度, $\mu=l^{\prime} / h^{\prime}$, および $k$ は柱の剛度に対す る梁の剛度の比で $k=\infty$ とした。

徳広らの強度式：塑性関節が側柱にのみ生じると限定 して,

$$
\begin{aligned}
& Q_{c a l}=\left(k \cdot F_{c}+p_{s} \cdot{ }_{s} \sigma_{y}\right) \cdot t \cdot l^{\prime}+Q_{s} \cdots \ldots \ldots \ldots . . . \\
& k=0.04+0.32 \frac{N_{0}}{A_{c} \cdot F_{c}}+0.09 \frac{p_{g} \cdot{ }_{g} \sigma_{y} \sum A_{c}}{t \cdot l^{\prime} \cdot F_{c}}
\end{aligned}
$$

ただし, $k \leqq 0.33+\left(6.1-{ }_{s} \sigma_{y} / F_{c}\right) \cdot p_{s}, A_{c}$ は側柱の断面積, ${ }_{g} \sigma_{y}$ は側柱主筋の降伏強度, および $Q_{s}$ は両側柱のせん 断力の和である。

益尾の強度式：付帯フレームの拘束が十分大きいとし $\tau$,

$$
\begin{aligned}
Q_{w u}= & \left\{0.444-0.076\left(F_{\mathrm{c}} / 200\right)\right\} \\
& \cdot\left(1+2 p_{s}{ }_{s} \sigma_{y} / F_{\mathrm{c}}\right) F_{c} \cdot t \cdot l
\end{aligned}
$$

\section{2 既往の強度式による実験値の評価}

ここでは, 表一1 の No. 1 42 の実験值と既往の強度 式による計算值との比較を行う。表一 4 に, 各強度式に よる計算値と計算値に対する実験値の比を示す。

富井・江崎の強度式の場合, 計算值と実験值には著し い相違がある。これは；スリップ破壊の定義にも起因す るが，強度式の基礎とした試験体の多くが比較的小さな 断面の付帯フレームで, 連層耐震壁を想定していないこ と，および側柱のせん断力のとらえ方に起因している。

望月（重）の強度式も連層耐震壁を想定していない。 強度式の基礎とした武験体が富井・江崎らの強度式誘導 の際に多く引用されていることもあって，富井・江崎の 強度式と同じ傾向を示す。また，局部的スリップ破壊が 生じていれば, 側柱と上・下梁に曲げ破壊またはせん断 破壊が生じている場合もスリップ破壊としていること, 付帯フレームの断面が小さいこと, および側柱のせん断 力を弹性応力として小さめに評価していることなどに起 因している。

徳広らの強度式も計算值は実験値に比べて小さい。強 度式の基礎とした試験体が鉄骨・鉄筋コンクリートで, 本研究で対象としている鉄筋コンクリートとは異なる が, 徳広らの定義したスリップ破壊は筆者らのそれと一 致し, また, 壁板コンクリートのスリップ破壊強度の評 価も, 拘束の大きい場合ほぼ一致している。しかし, 強 度式において変動軸力を考慮していないこと,および拘 束の評価方法に起因して側柱と壁板のせん断力が低く評 価される傾向があり，これが計算値と実験值に比べて小 さくしている。

益尾の強度式の場合, 他の強度式と同様, 計算値は夷 験值に比べて小さい。これは，コンクリート強度の大き い試験体では，コンクリートのスリップ破壊強度が低く
評価されること,および側柱のせん断力を考慮していな いことに起因している。これらの強度式については, 再 度, 5.3.3 で検討される。

5.3 提案強度式亡既往の強度式による他の実験値の評価 4.3 および 5.2 において, 提案強度式 (8) が, 既往 の強度式に比べて実験値をよくとらえていることを示し たが，これは強度式の基礎とした実験データについての 比較であるから, 当然の結果ともいえる。

また, 強度式（8）の基礎とした試験体は, すべて一 方向対角圧縮力をうけたものである。この一方向対角圧 縮力をうける試験体の強度は, 他の, 例えば一方向対角 圧縮力・他方向対角引張力をうける場合に比べて大きく なるとの指摘 ${ }^{14)}$ がある。このため, 富井・江崎は, 一方 向対角圧縮力をうける試験体を基礎とする実験データか ら除外している。しかし, 強剛な付帯フレームをもつ場 合, 側柱の変動軸力を考慮して側柱のせん断力を的確に 評価できれば, 強度式のデータとして一方向対角圧縮力 の試験体は有用と考えられる。ここでは, 別の試験体に ついて各強度式による評価を試みる。

\subsection{1 対象とした試験体}

本研究で定義したスリップ破壊は, 強剛な上・下梁と せん断破壊しない側柱をもつ耐震壁で，スリップ破壊時 に側柱の上端と下端でのみ曲げ降伏している破垻モ一ド である。表一1の試験体番号 No. 43６4 として揭げた 22 体 $^{31}$ 151 211 は, 実験で壁板のスリップ破壊によって最 大強度に達し，5.3.2 の手順による計算で側柱の軸引張 降伏が認められなかったものである。試験体の珯性質の うち, 計算に必要な数值を各文献から引用してある。試 験体の加力方法は $h^{\prime} \cdot r, \tan \theta_{p}$, および $N_{0}$ で示される。 ただし， $r$ は反曲点高さ比, $\theta_{p}$ は作用外力の傾斜角で ある。試験体番号 No. 43 No. 47 は連続梁形式の曲げ・ 世九断加力, No. 48 55, No. 60 63 は一方向対角圧縮 加力, その他は片持柱形式の曲げ・せん断加力である。

\section{3 .2 計算の手順}

一方向対角圧縮力をうける試験体を除けば，両側柱の 応力分布は対称でない。このため，一般的な外力条件に 対応する耐震壁のスリップ破壊せん断強度式として, 式

（8）を次の形に変更する。

$$
Q_{\text {cal }}=0.313 F_{c} \cdot t \cdot l \cdot+\sum_{c} Q_{y}
$$

$$
\text { ここで, } \Sigma_{c} Q_{y} \text { は次式で表される。 }
$$

$$
\sum_{c} Q_{y}=\left({ }_{t t} M_{y}+{ }_{l b} M_{y}+{ }_{r t} M_{y}+{ }_{r b} M_{y}\right) / h^{\prime}
$$

ただし, ${ }_{t} M_{y},{ }_{b o} M_{y}$ と ${ }_{r t} M_{y},{ }_{r b} M_{y}$ は, それぞれ, 左側柱 と右側柱の上端と下端の曲げ降伏強度である。この $\Sigma$ ${ }_{c} Q_{y}$ は, 本研究で対象としている壁板の全域が有効であ るスリップ破壊の場合, 側柱の上端と下端が曲げ降伏状 態にあるときの両側柱のせん断力の和になる。

式（13）の計算の手順を表一 5 に示す。 


\subsection{3 計算結果}

各強度式による計算値，および計算值に対する実験値 の比 $Q_{\text {exo }} / Q_{c a l}$ を表一 4 に示す。益尾の強度式 (12)の 基礎としたデータの中にNo.43〜47 が含まれているこ ともあって，強度式（12）は，強度式（13）とともに実 験値をよくとらえている。表一1の全試験体について，

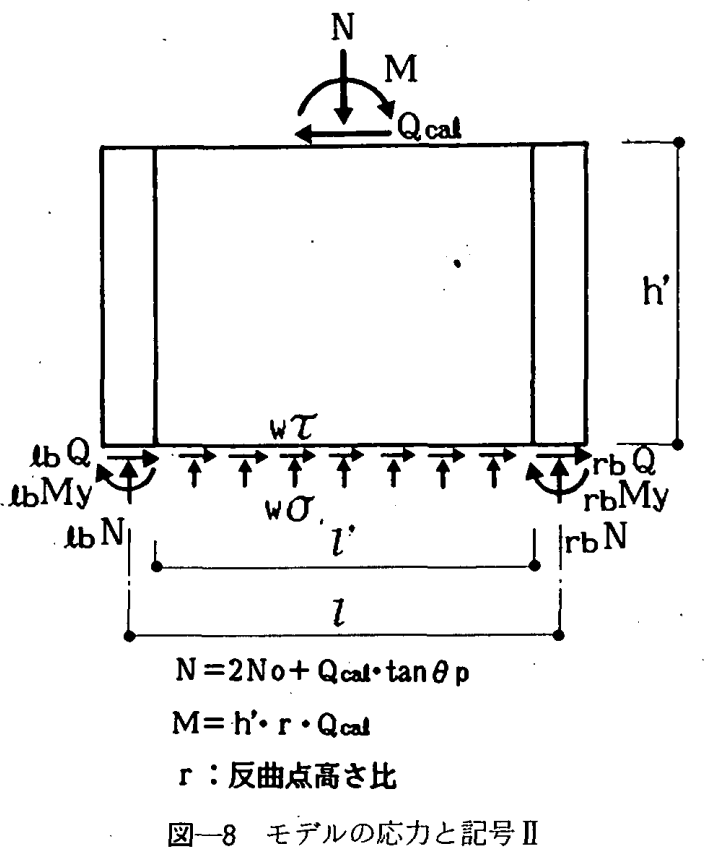

強度式（13）による $Q_{\text {exo }} / Q_{c a l}$ の平均，標準偏差，およ び変動係数の值は，0.973，0.103，および 0.106 である。 また，強度式（13）の相関係数の值は 0.988 である。こ れらは，既往の強度式に比べてよい值を示している。

耐震壁の強度にかかわる主なパラメー夕は，コンク リ一ト強度 $F_{c}$, 壁板の補強筋比 $p_{s}$, 耐震壁の全幅に対 する壁板の内法高さの比 $h^{\prime} /(l+D)$ ，曲げモーメント分 布の反曲点高さ $h^{\prime} \cdot r$, 耐震壁の全断面積に対する側柱 の断面積の比 $A_{c} /\left(\sum A_{c}+A_{w}\right)$ ，側柱の全主筋比 $p_{g}$ ，お

\section{表一5＼cjkstart計算の手順}

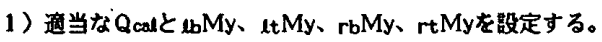

2）时柱の軸力を次式から求める(图一6(b)およU゙图一8)。 $l_{b} \mathrm{~N}=-\left(\mathrm{lb} M y+r b M y-N \cdot l / 2+M-Q_{c a l} \cdot h^{\prime}+w \sigma \cdot t \cdot l \cdot l / 2\right) / l$ $r_{b} N=\left(e b M y+r b M y+N \cdot l / 2+M-Q_{c a l} \cdot h^{\prime}-w \sigma \cdot t \cdot l \cdot l / 2\right) / l$ et $N=\ell b N-w \tau \cdot t \cdot h^{\prime}$

$\mathrm{rt} N=r \mathrm{~b}+w \tau \cdot t \cdot h^{\prime}$

ただし、 $\sigma \sigma=0.313 \mathrm{Fc}-\mathrm{ps} \cdot \mathrm{s} \sigma \mathrm{y}$ $w \tau=0.313 \mathrm{Fc}$ $M=\left(h^{\prime}-r \cdot h^{\prime}\right) \cdot Q_{\text {cal }}$ $\mathrm{N}=2 \mathrm{No}+Q_{\mathrm{cal}} \cdot \tan \theta p$

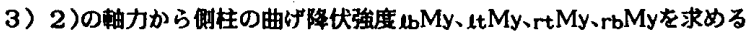
ただし、相力か降伏強度を超える場合、曲㚈降伏強度は零とする。

4) Qcal $=w \tau \cdot t \cdot l+\left(\ell b M y+\iota_{t} M y+r b M y+r t M y\right) / h$ をを求める。

5）Qcalts収束するまで2)〜4)を程り返す。

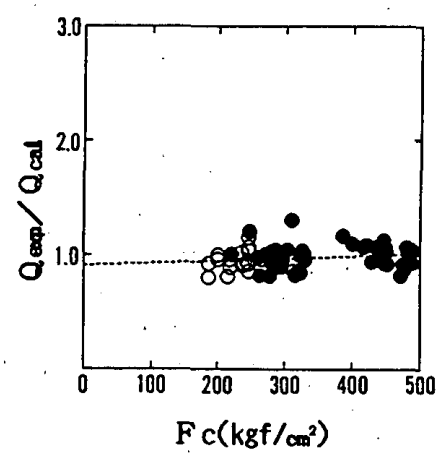

(a) $\frac{Q_{\text {exp }}}{Q_{\text {cal }}}\left\llcorner F_{c}\right.$

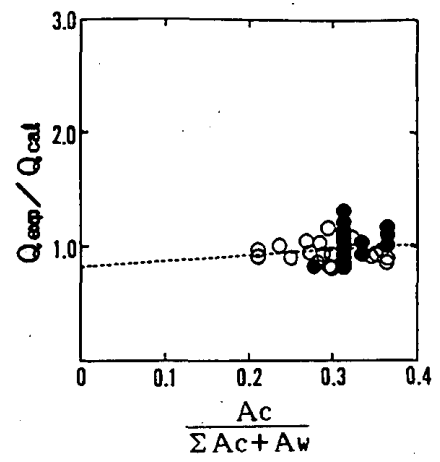

(d) $\frac{Q_{\text {exp }}}{Q_{c a l}} と \frac{A_{c}}{\sum A_{c}+A_{w}}$

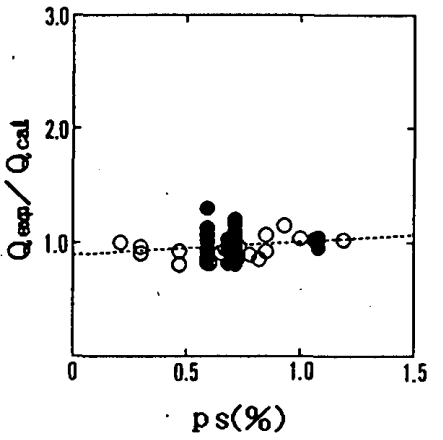

(b) $\frac{Q_{\text {exp }}}{Q_{\text {cal }}}$ ¿ $p_{s}$

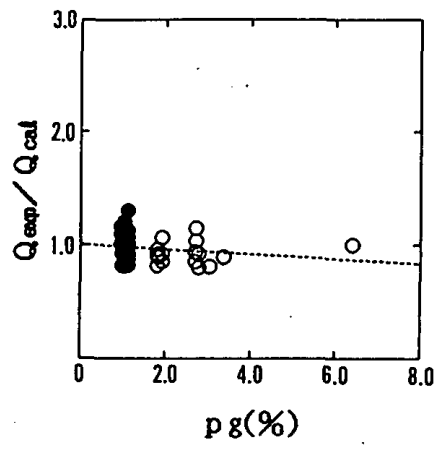

(e) $\frac{Q_{\text {exp }}}{Q_{\text {cal }}} \Leftarrow p_{g}$

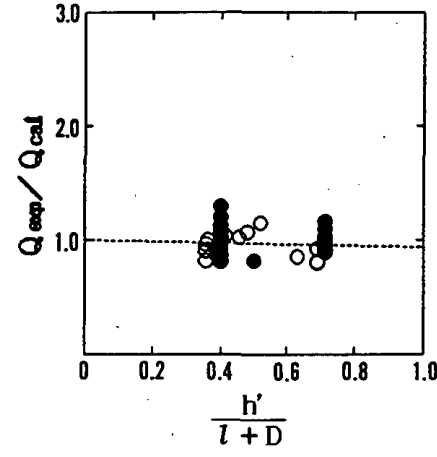

(c) $\frac{Q_{\text {exp }}}{Q_{\text {cal }}}$ と $\frac{h^{\prime}}{l+D}$

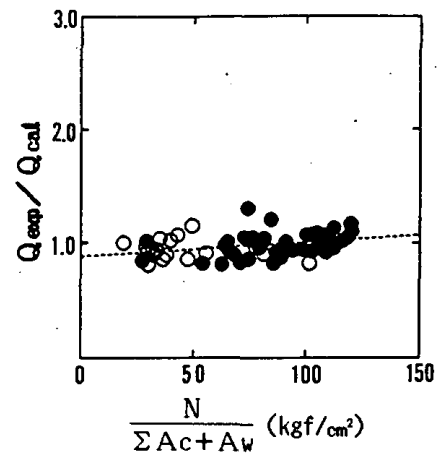

(f) $\frac{Q_{\text {exp }}}{Q_{\text {cal }}}$ と $\frac{N}{\sum A_{c}+A_{w}}$

図一9 強度式（13）による $\frac{Q_{\text {exp }}}{Q_{c a l}}$ とパラメータの関係 

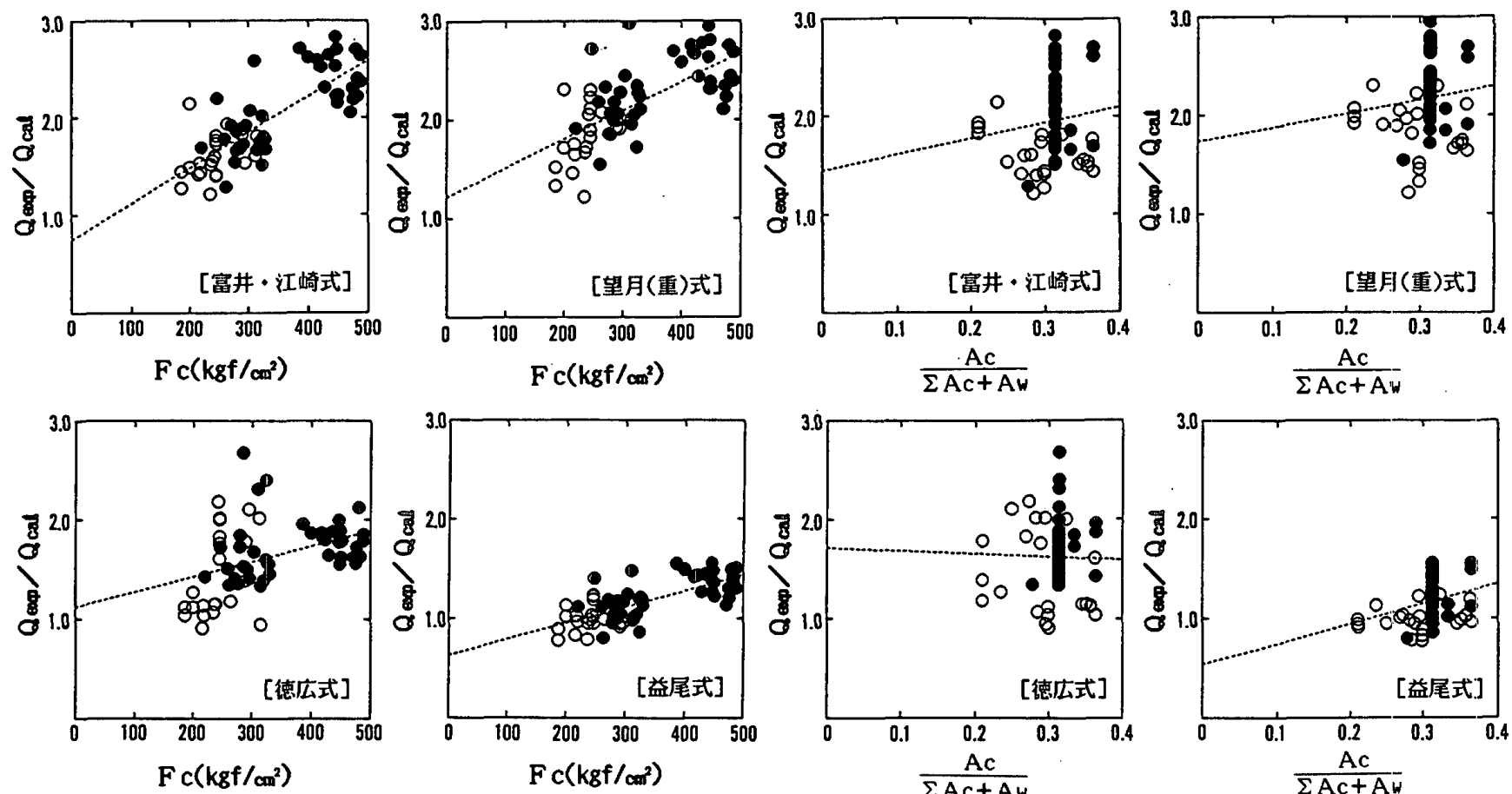

(a) $\frac{Q_{\text {exp }}}{Q_{\text {cal }}}$ ¿ $F_{c}$
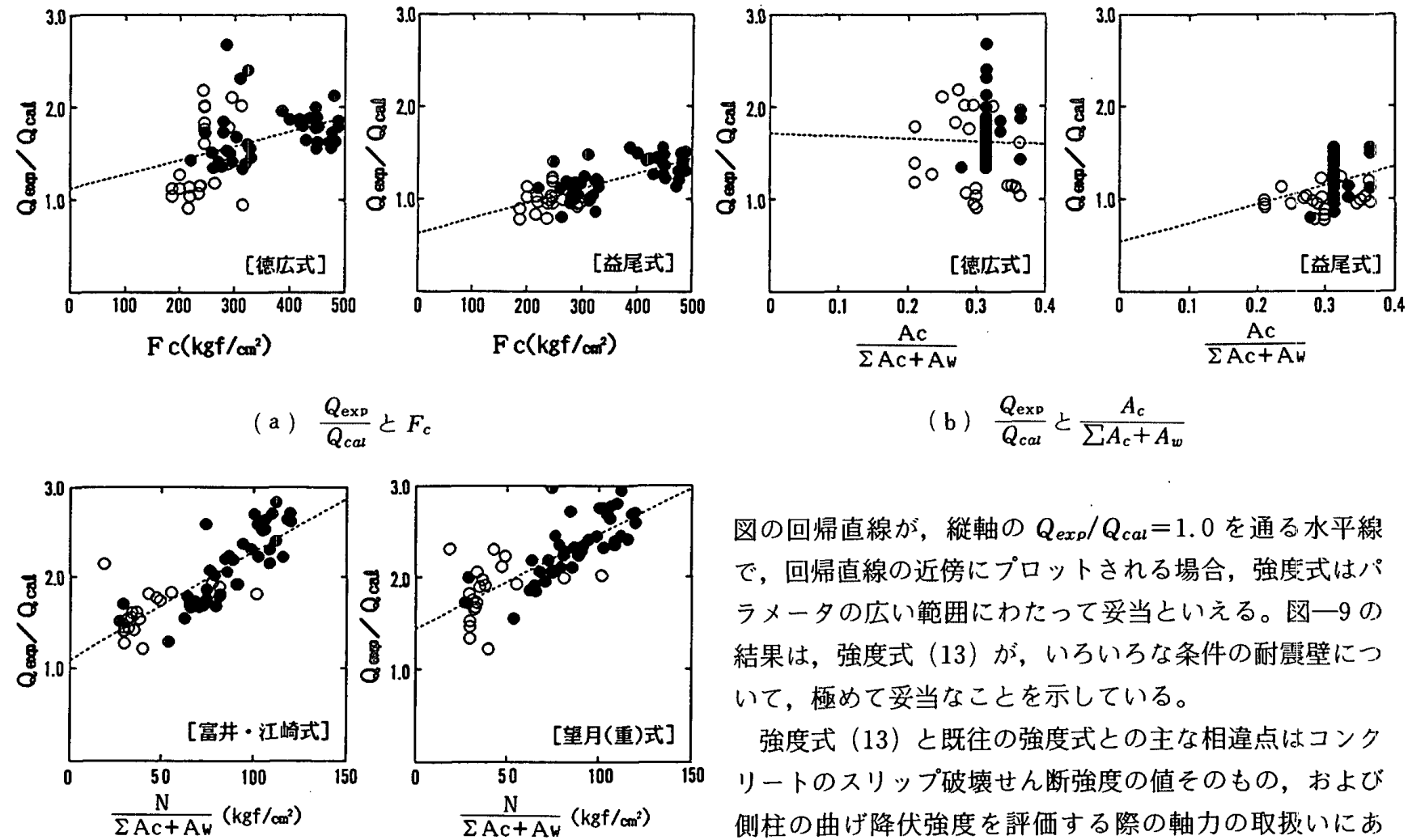

(b) $\frac{Q_{\text {exp }}}{Q_{\text {cal }}}$ と $\frac{A_{c}}{\sum A_{c}+A_{w}}$

図の回帰直線が, 縦軸の $Q_{\text {exo }} / Q_{c a l}=1.0$ を通る水平線 で，回帰直線の近傍にプロットされる場合，強度式はパ ラメータの広い範囲にわたって妥当といえる。图一9の 結果は, 強度式 (13) が, いろいろな条件の耐震壁につ いて，極めて妥当なことを示している。

強度式（13）と既往の強度式との主な相違点心コンク リートのスリップ破壊せん断強度の値そのもの, および 側柱の曲げ降伏強度を評価する際の軸力の取抔いにあ る。図一10は，既往の強度式による $Q_{\text {exo }} / Q_{c a t}$ をパラ メータ $F_{c}, A_{c} /\left(\sum A_{c}+A_{w}\right)$, および $N /\left(\sum A_{c}+A_{w}\right)$ につ いてプロットしたものである。罒は, 既往の強度式の $Q_{e x \rho} / Q_{c a l}$ がこれらのパラメータの值が大きくなるのに つれて大きくなることを示している。このことは、スリッ プ破壊で終る連層耐震壁の最大強度の評洒には, コンク リートのスリップ破壊強度の評価, および変動軸力をも 考慮した側柱のせん断力の評価が重要であることを示し ている。

\section{6. 結 び}

图一10 既往の強度式による $\frac{Q_{e x p}}{Q_{c a l}}$ とバラメータの関係

よび耐震壁の全断面積に対する最大強度時の全作用軸力 の比 $N /\left(\sum A_{c}+A_{w}\right)$ である。ここで, $A_{w}$ は壁板の断面積, および $N=2 N_{0}+Q_{e x \rho} \tan \theta_{\rho}$ である。図一 9 は, 強度式 （13）による全試験体の $Q_{\text {exp }} / Q_{c a l}$ を $h^{\prime} \cdot r$ を除く各パ ラメータについてプロットしたものである。図中の黒丸 がNo. 1 42 の, 白丸がNo. 43〜64のデータである。

本研究は, 強剛な上・下梁とせん断破壊しないよう補 強された側柱をもつ耐震壁が, 壁板のスリップ破壊で最 大強度に達した実験から，スリップ破壊せん断強度式を 提案している。また，提案強度式を別の実験結果に適用 し, 既往の強度式と比較している。その結果は, 提案強 度式が既往の強度式に比べて, パラメータの広い範囲に わたって実験結果をよくとらえていること,また, スリッ プ破壊せん断強度の評価には，コンクリートのスリップ 
破壊強度に加えて，変動軸力をも考慮した側柱のせん断 力の評価が重要であることを示している。

提案強度式は強剛な上・下梁をもつ耐震壁がせん断破 壊モードのスリップ破壊で終る場合に限定されている。 より明確にいえば,

1）作用外力のもとで側柱の軸引張降伏が生じないほ

ど，定軸力が大きいか，または主筋量が多い，

2) スリップ破壊時の壁板の拘束反力によって側柱にせ ん断破壊が生じないよう補強されている, の場合に限定される強度式である。

\section{参考文献}

1) Masahide Tomii, Fumiya Esaki : Expression for Cal culating Lateral Shear Capacity of One-Bay One-Story Reinforced Concrete Framed Shear Walls Failing in Slip Shear of Their Infilled Wall Panel, 日本建築学会 構造系論文報告集，第 306 号, pp. 142 151, 昭和 61 年 8 月

2）望月 重：鉄筋コンクリート耐震壁の終局せん断強度に 関する研究一壁板のスリップ破壊に支配される酎力一, 日本建築学会論文報告集，第 330 号，pp. 86 95，昭和 58 年 8 月

3）徳広育夫, 三谷 勲, 宮崎博茂: 周辺架構の構造形式が 異なる耐震壁の破壊形状とせん断耐力に関する実験的研 究, 日本建築学会構造系論文報告集, 第 355 号, pp. 88 -97, 昭和 60 年 9 月

4）益尾 潔：鉄筋コンクリート耐震壁のせん断耐力に関す る研究, 日本建築学会構造系論文報告集, 第 380 号, pp. 76 86, 昭和 62 年 10 月

5）望月 洵, 竹原雅夫： $\mathrm{RC}$ 連層酎震壁のせん断強度に関 する実験的研究, 日本建築学会大会学術講演梗概集, pp. 1441 1444, 昭和 57 年 10 月

6) Makoto Mochizuki, Tohru Katagiri, Masayoshi Umeda : A Study on the Slip Shear Failure of Layered Shear Wall Frame System, PROCEEDINGS of 9 WCEE, Vol. IV, pp. $511 \sim 516,1988.8$

7) 日本建築学会：建築耐震設計における保有耐力と変形性 能, p. 160, 昭和 60 年 5 月

8）称原良一, 加藤 勉：鉄筋コンクリート連層耐震壁の終 局耐力, 日本建築学会論文報告集, 第 343 号, pp. 24 31, 昭和 59 年 9 月

9）白石一郎, 狩野芳一, 町田亘寛: 鉄筋コンクリート造耐
震壁の最大強度に関する一考察, 日本建築学会構造系論 文報告集，第 365 号，pp. 144 - 155, 昭和 61 年 7 月

10）村上利憲, 福嶋孝之, 南 宏一：水平集中荷重を受ける 鉄骨鉄筋コンクリート耐震壁のせん断強度, 日本建築学 会近畿支部研究報告集, pp. 205 208, 昭和 60 年 5 月

11）塩原 等：塑性理論を応用した鉄筋コンクリート耐震壁 の終局強度算定方法, コンクリート工学, Vol. 25, No. 8, pp. $101 \sim 113,1987.8$

12）望月 洵, 小野里憲一：連層耐震壁のマクロモデルとそ の解析法, コンクリート工学論文集, 第 1 巻第 1 号, pp. 121 132, 1990. 1

13）大久保雅章, 浜田 瞈, 野口 博: 地震時のひび割れコ ンクリートの圧縮特性の劣化に関する基礎実験, JCI コ ロキウム「RC 構造のせん断設計法に関する解析的研究」 論文集, pp. 17 22, 1989. 10

14）日本建築学会：建築構造物のリミットアナリシス, pp. 304 , 昭和 38 年 7 月

15）望月 洵, 一竹原雅夫：R.C. 連層耐震壁のせん断破壊に 関する研究, 日本建築学会大会学術講演梗概集, pp. $1847 \sim 1848$, 昭和 59 年 10 月

16）望月 洵, 片桐 徹, 梅田正芳 : 連層耐震壁のせん断破 壊に及ぼす柱の拘束の効果について, 日本建築学会大会 学術講演梗概集, 構造 II, pp. 391 - 392, 昭和 62 年 10 月

17）望月 洵, 竹原雅夫, 小野里憲一：連層耐震壁のスリッ プせん断強度式とその妥当性について, 日本建築学会大 会学術講演梗概集, 構造 II, pp. 565 566, 昭和 63 年 10 月

18）狩野芳一, 高木仁広：小型 3 層鉄筋コンクリート耐震壁 の強度及び変形性能に関する実験的研究（壁厚の違いに よるせん断破壊性状の相違について), 日本建築学会大会 学術講演梗概集, pp. 1535 1536, 昭和 54 年 9 月

19）山田 稔, 河村 広, 細田安章：鉄筋コンクリート耐震 壁の弾性変形並びに崩壊性状に関する研究（梁が比較的 剛な場合), 日本建築学会大会学術講演梗概集, pp. 1659 $\sim 1660$, 昭和 53 年 9 月

20）山田 稔, 河村 広, 稲田明人：鉄筋コンクリート耐震 壁の弾性変形並びに崩壊性状に関する研究（II. 柱材の 効果), 日本建築学会近畿支部研究報告集, pp. 65 68, 昭和 54 年 6 月

21）建屋の復元特性に関する研究委員会：建屋の復元特性に 関する研究 (その13) 開口を有する耐震壁の実験, 建築 振興協会, 昭和 61 年 6 月

(1990 年 3 月 10 日原稿受理, 1990 年 7 月 21 日採用決定) 